\title{
The Role Of Turkish Central Bank During And After The 2008-Financial Crises
}

\author{
Ayhan Guney, Yalova University, Turkey
}

\begin{abstract}
The Global Financial Crises occurred at the end of 2008, and in very short time, spread to all sectors of economy. All countries were badly hit by the crises and the World economies shrank almost $\$ 50$ trillion, the equivalent of one year of world GDP. During the process, especially the banking sectors of the world economies was smashed, and many banks and financial institutions bankrupted and some others liquidated such as Lehman Brothers. All countries took the drastic fiscal and monetary measures to overcome the global crises. So, this paper focuses on the functions of central banks asking that what the role of central banks to cope with the global crises was, and thus omits the side of fiscal policies implemented by different countries. It especially discusses the role of Turkish Central Bank and its monetary policies during and after the 2008Global Financial Crises. What was the achievement of the measures taken and the monetary policies implemented by Turkish Central Bank during and after the financial crises?
\end{abstract}

Keywords: The Role of Turkish Central Bank; 2008-Financial Crises; Monetary Policies

\section{INTRODUCTION}

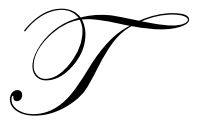

he Global Financial Crises occurred at the end of 2008, and in very short time, spread to all sectors of economy. All countries were badly hit by the crises and the World economies shrank almost $\$ 50$ trillion, the equivalent of one year of world GDP. (Aisen Ari., Franken Michael, p.4) During the process, especially the banking sectors of the world economies was smashed, and many banks and financial institutions bankrupted and some others liquidated such as Lehman Brothers. All countries took the drastic fiscal and monetary measures to overcome the global crises. The main reason of the meltdown of the financial system, that is, the financial crises was the loose monetary polices in the developed countries. So, this paper omits the side of fiscal policies implemented by different countries and focusing on the functions of central banks asking that what the role of central banks to cope with the global crises was? It especially discusses the role of Turkish Central Bank and its monetary policies during and after the 2008-Global Financial Crises. What was the achievement of the measures taken and the monetary policies implemented by Turkish Central Bank during and after the financial crises?

Turkey grew by 8.9 percent in 2010 following China and Argentina. What was the role of Turkish Central Bank in this process? Political stability was very important factor in 9 percent-growth of the Turkish economy. The mid-term economic program declared by the government during the global crisis-2008 reduced the risk and uncertainties towards the future of the Turkish economy. It is obvious that the expectations with regards to the economic development of Turkey were successfully managed by Turkish government during the crises.

Table: 1

\begin{tabular}{|l|l|}
\hline Financial Crises-2008 & What Happened in general \\
\hline & -Recession in all general economic activities \\
& -Decrease of Inflation \\
& -Decrease in Commodity Prices \\
& -Shortage in Aggregate Demand \\
& -Slowing down in Credit Canals of Banks \\
\hline
\end{tabular}


The recent global financial crises demonstrated that the financial regulation for the world economies which was designed in the GATT negotiations in 1944 and got stronger after the 1980, have had many causes of vulnerability. It also showed that the current global financial system is very sensitive and vulnerable to the external shocks and could be easily speculated and manipulated which means that it is very risky for the real economic system. From the economist, Paul Krugman, the analysis regarding the global financial crises in his book, we obviously understand that the great financial reform is necessary for the global financial system, which could be offered and designed by the emerging markets and economies in the near future.

\section{Crises Effect on the Turkish Economy}

The Global Financial Crises affected badly the Turkish economy by reducing aggregate demand together with the sharp fall in commodity prices and inflation and by limiting financing instruments and bank's credit channels and financing policies.

First, the Turkish economy got the strong signal in the late 2009 towards the recovery of the Turkish economy from the crises because the economy grew by 6 percent in last quarter of 2009 which was the first time after crises and continued to systematically grow by now. The Turkish economy has been growing for the last consecutive 15 quarters. It obviously means that the Turkish economy succeed to get rid of the crises in the shorter time than anticipated and, record to grow by 9.8 percent in 2010 following China and Argentina all over the World. How and why the Turkish economy accomplished the crises while the EU economies such as Greece, Spain and Portuguese economies are having still economic difficulties and striving against the turmoil because of the huge public and foreign debt.

Political stability was very important factor in 9.8 percent-growth of the Turkish economy behind this accomplishment. The mid-term economic program declared by the government during the global crisis-2008 reduced the risk and uncertainties towards the future of the Turkish economy. It is obvious that the expectations with regards to the economic development of Turkey were successfully managed by the government through the fiscal discipline and monetary policies. Besides this, the most important thing is that the trust or confidence to Turkish economy was increased by the public and businesses since the decision makers who are responsible for economic policies took the right measures on time. Public trust to Turkish economy depends on the political and economical stability in Turkey. Investors' and consumers' trust to Turkish economy helped in becoming the success of the monetary and fiscal policies during the crises. process?

Apart from the things mentioned all above, what was the specific role of Turkish Central Bank in this

\section{Turkish Central Bank Policies between 2008-2010}

Turkish Central Bank played very important role during the crises taking some measurements on time. As soon as the crises appeared and spread quickly to all over the world, the developed countries such as the USA, the $\mathrm{EU}$, and etc., took very immediate and drastic measures and, in the meantime, the Turkish Central Bank put simultaneously in practice the right monetary policies in harmonized with the Turkish government fiscal policies. Turkish Central Bank Policies aimed at the restoring of price, financial and economic stability in public sector by using the policy tools such as interest rate, liquid funds, and reserve ratio requirements in order to increase the total demand in economy when economy was in recession because of the crises. Thus, the Turkish Central Bank played very significant role in recovering from the crises through the monetary tools. Then, what were the measures taken and the monetary policies implemented by Turkish central bank during and after the financial crises? Almost every central bank of other countries used the same macroeconomics policy tools, but why it was more successful in Turkey?

The economic monetary measures that have been taken by the Turkish Central Bank and Turkish Government during the crises can be summarized as follows (Table 2). 
Table: 2

\begin{tabular}{|c|c|}
\hline Institutions & Measures \\
\hline Turkish Central Bank & $\begin{array}{l}\text {-Cut in Interest Rate } \\
\text {-Reduction in Required Reserve Ratio } \\
\text {-Intermediation activities in exchange rule and effective markets have started until the } \\
\text { uncertainty in international markets reduces }\end{array}$ \\
\hline Turkish Government & 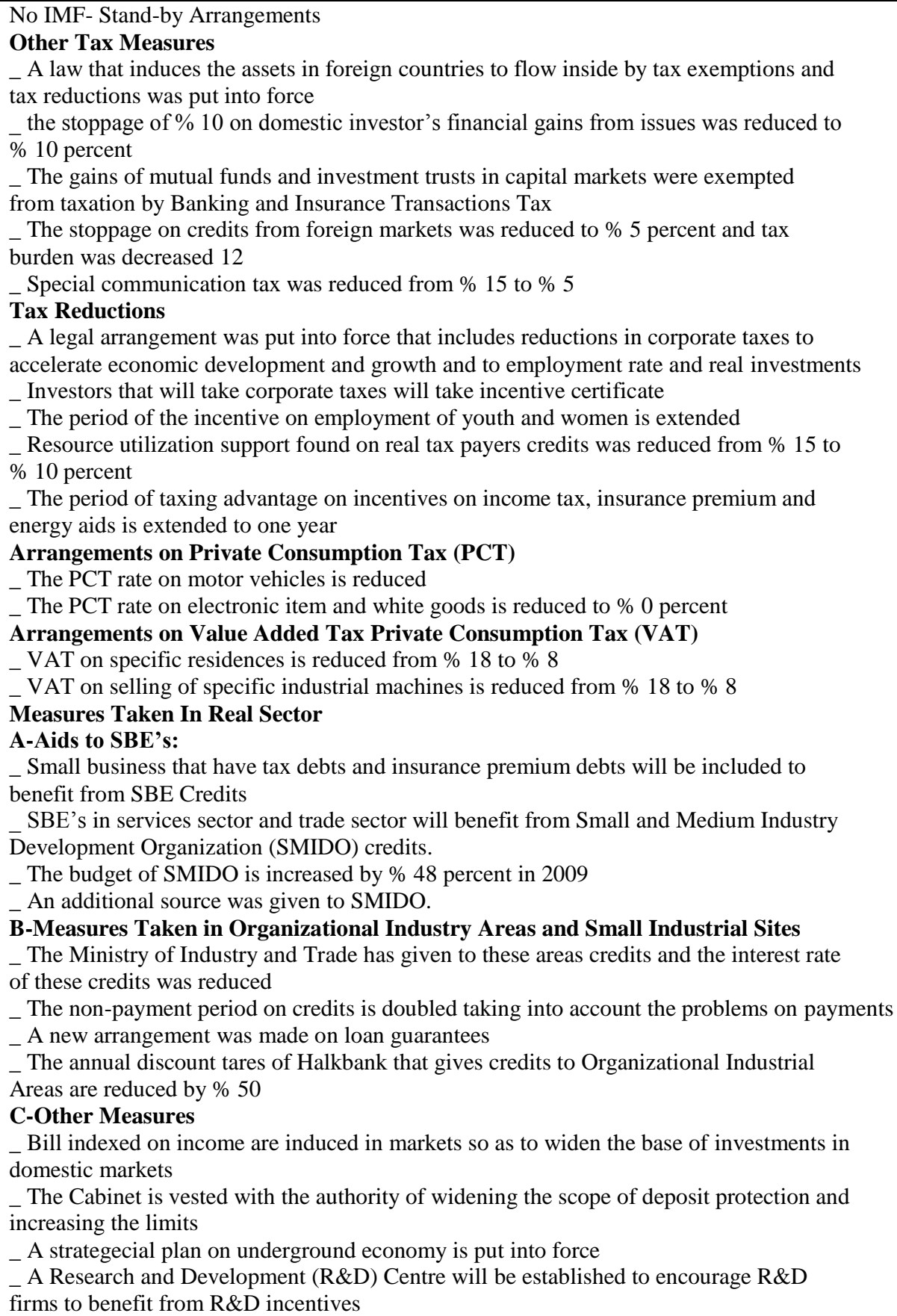 \\
\hline
\end{tabular}

Source: Erdönmez, Pelin Ataman, "Küresel Kriz ve Ülkeler Tarafından Alınan Önlemler Kronolojisi”, Bankacılar, Sayı: 68, Mart 2009, pp.85-101

Tandircioglu, Haluk,(2009), Effects of Global Crises on Turkish Economy, http://www.iefpedia.com/english/wpcontent/uploads/2010/01/EFFECTS-OF-GLOBAL-CRISIS-ON-TURKISH-ECONOMY-Dr.-HalukTANDIRCIO\%C4\%9ELU.pdf 
As summarized in Table-2 above, the Turkish Central Bank reduced the interest rates in November of 2008 and, in this regard it implemented the expansionary monetary policies during the global crises because of the shortage of demand in the market.( TCMB, 2009 Report, p.2) During the crises, the anxiety about inflation target policies has already been declined because of the shortages of the aggregate demand. Thus, it prepared the appropriate economic environment for the central bank to focus on the financial stability.( TCMB, 2009, p.2) It can be interfered that the Turkish Central Bank played very successful role in recovering from the crises in shorter time compared to the neighboring EU countries and the USA. Another reason why the Turkish Central Bank was so successful in Turkey was that Turkish entrepreneurs and investors and households which are the major economic player, trusted very much the Turkish Economy during the crises.

\section{CONCLUSION}

It is strongly understood that the global financial system needs necessarily the radical financial reform, which could be potentially offered and designed by the emerging markets and economies in the near future. The recent crises confirmed that the sustainability of the current financial system by designed the developed countries after the GATT negotiations is unlikely to proceed in this way since the present financial system continue to produce other financial crises because of its ability to create financial crises and economic chaos all the time. The fundamental reason for this is that the financial sector has grown 12 time faster than the real sector of economies in the world, which means that the player in the financial sector made money 12 times bigger than the ones in the real sector without producing any goods and services. By nature, the current financial system has greatly stimulated the investor to invest their money to financial instruments rather than the real instruments as they bring about the faster money earning. Thus, investing in non-real instruments has rapidly inflated the financial sector in the last three decades. As a result, financial sector has been much bigger than real production sector for years. To prevent from the future financial crises, the financial system should be again designed in accord with real economic sector rules.

\section{AUTHOR INFORMATION}

Ayhan Guney, Ph.D., is currently working Assistant Professor in Economics at Yalova University in Turkey since 2010. Also, he is visiting scholar in West Chester University of Pennsylvania, PA, USA for 2011-2012 academic years. He graduated from the Faculty of Political Science of Ankara University in 1995. He completed Master of Arts in Economics at Fatih University. He got a PhD degree in economics from both the National Sciences Academy and Istanbul University. He worked as the Director of International Office and MBA Coordinator and thought microeconomics, macroeconomics and international economics in English language at Qafqaz University, Baku, for 2007-2010 academic years. He was a visitor scholar at the Queen's Belfast University, Belfast, UK for a term in 2009. E-mail: ayhang79@hotmail.com

\section{REFERENCES}

1. Aisen Ari., Franken Michael (2010), Bank Credit during the 2008 Financial Crisis: A Cross-Country Comparison, IMF Working Paper, 28 May 2010, http://www.imf.org/external/pubs/ft/wp/2010/wp1047.pdf, 12 April, 2011

2. Erdönmez, Pelin Ataman, "Küresel Kriz ve Ülkeler Tarafindan Alınan Önlemler Kronolojisi”, Bankacılar, Say1: 68, Mart 2009, pp.85-101 http://www.tbb.org.tr/Dosyalar/Dergiler/Dokumanlar/68.pdf

3. Rodrik Dani (2009), the Turkish Economy after the Crises, 27 November 2009, http://www.tek.org.tr/dosyalar/RODRIK-TEK.paper.pdf, 10 April, 2011

4. Tandircioglu, Haluk,(2009), Effects of Global Crises on Turkish Economy, http://www.iefpedia.com/english/wp-content/uploads/2010/01/effects-of-global-crisis-on-Turkisheconomy-Dr.-Haluk-Tandircio\%C4\%9ELU.pdf, 18 April 2011.

5. TCMB(Turkiye Cumhuriyeti Merkez Bankasi), 2010 Yilinda Para ve Kur Politikasi, 10 December 2009, http://www.tcmb.gov.tr/yeni/duyuru/2009/Baskan_ParaPol10.pdf, 12 April 2011.

6. TCMB(Turkiye Cumhuriyeti Merkez Bankasi), 2011 Yilinda Para ve Kur Politikasi, 21 Dcember 2010, http://www.tcmb.gov.tr/yeni/duyuru/2010/Baskan_ParaPol11.pdf, 12 April 2011

7. Yilmaz, Durmus(2009), Turkey's Monetary and Exchange Rate Policy for 2009, BIS Review 3/2009. 